\title{
The Dynamics Between Value Co-creation and Value Co-destruction in Business Service Networks
}

\author{
Chavi C.-Y. Fletcher-Chen, Loïc Plé, and Xia Zhu
}

\begin{abstract}
Understanding value creation processes between actors in businessto-business (B2B) settings is crucial (Lindgreen and Wynstra 2005). To that end, service-dominant logic (SDL) proposes that value co-creation is derived from interactions between service systems (e.g. customers, distributors, suppliers, etc.) (Vargo et al. 2008; Lusch and Vargo 2006). These interactions may occur and be studied not only at the dyadic but also at the network level (Cova and Salle 2008; Vargo et al. 2008). At the same time, research has mainly focused on value co-creation, and left aside the possibility of value co-destruction, or the potential dynamics between value co-creation and value co-destruction (Plé and Chumpitaz-Caceres 2010). However, Zhu and Zolkiewski's (2015) show that a domino effect is evident in the chain of upstream service provider to service recipients and their downstream customers in a business-to-business service setting. This chain of interaction shows the complexity of multiparty relationships (Andersson-Cederholm and Gyimothy 2010). It also indicates that value co-creation and value co-destruction may be contingent in the service network but does not explain how value co-creation and co-destruction processes may be intertwined in a B2B service network, while such knowledge is needed (Cova et al. 2011; Payne et al. 2008; Echeverri and Skålén, 2011; Lindgreen et al. 2012). This empirical study aims to contribute to this gap by investigating how the nature of interacting actors, their activities, and the mobilization of their resources in a network influence the dynamics between value co-creation and value co-destruction in B2B service networks. In order to gain a holistic understanding of the phenomenon, a case study has been used to collect qualitative data from suppliers-distributors-customers triads. Preliminary findings will be presented in the conference.
\end{abstract}

\section{References Available Upon Request}

C.C.-Y. Fletcher-Chen $(\bowtie) \bullet$ L. Plé

IÉSEG School of Management, Université Catholique de Lille (LEM UMR CNRS 9221),

Lille, France

e-mail: c.chen@ieseg.fr; 1.ple@ieseg.fr

X. Zhu

Keele Management School, Keele University, Staffordshire, UK

e-mail: x.zhu@keele.ac.uk 